How to Cite: Jumadilov, T.K., Utesheva, A.A., Khimersen, Kh., Kondaurov, R.G., \& Grazulevicius, J.V. (2021). Abnormal activity of functional groups during uranyl ions sorption by polymethacrylic acid-poly-4-vinylpyridine intergel system. Bulletin of the University of Karaganda - Chemistry, 104(4), 47-56. https://doi.org/10.31489/2021Ch4/47-56

UDC 541.132/.132.4:541.49

\author{
T.K. Jumadilov ${ }^{1}$, A.A. Utesheva ${ }^{2,3^{*}}$, Kh. Khimersen ${ }^{1,4}$, \\ R.G. Kondaurov ${ }^{1}$, J.V. Grazulevicius ${ }^{5}$ \\ ${ }^{I}$ Institute of Chemical Sciences named after A.B. Bekturov, Almaty, Kazakhstan; \\ ${ }^{2}$ Kazakh-British Technical University, Almaty, Kazakhstan; \\ ${ }^{3}$ Institute of High Technologies, Almaty, Kazakhstan; \\ ${ }^{4}$ Abai Kazakh National Pedagogical University, Almaty, Kazakhstan; \\ ${ }^{5}$ Kaunas University of Technology, Kaunas, Lithuania \\ (*Corresponding author's e-mail: utesheva_93@bk.ru)
}

\title{
Abnormal activity of functional groups during uranyl ions sorption by polymethacrylic acid-poly-4-vinylpyridine intergel system
}

\begin{abstract}
Uranyl ions sorption by intergel system consisting of polymethacrylic acid hydrogel (hPMAA) and poly-4vinylpyridine hydrogel (hP4VP) has been studied. First, reciprocal activation of PMAA and P4VP polymeric hydrogels in water environment was examined in order to predict intergel system sorption activity. Based on the obtained results, it was found that area of maximum hydrogel activation was within the ratios of $100 \%$ hPMAA and $67 \%$ hPMAA:33\% hP4VP. The maximum rate of uranyl ions extraction was also observed within these ratios. The highest uranyl ions sorption by intergel system occurred at $83 \%$ hPMAA:17\% hP4VP ratio. Maximum uranyl ions extraction rate after 56 hours of hydrogels remote interaction was $82.5 \%$, when polymeric chain binding rate was $9.94 \%$ and effective dynamic exchange capacity was $1.12 \mathrm{mmol} / \mathrm{g}$. Significant increase of intergel system sorption activity within the ratios of $100 \%$ hPMAA and $67 \%$ hPMAA:33\% hP4VP in comparison with initial inactivated hydrogels $100 \%$ hPMAA and $100 \%$ hP4VP was confirmed by combined calculation data of extraction rates of inactivated PMAA and P4VP polymeric hydrogels. The obtained results illustrated changes of initial polymeric hydrogels' electrochemical sorption properties in intergel system leading to functional groups obtaining higher reactive ability, which made it possible to use them for further development of highly efficient uranyl ions extraction sorption technology.
\end{abstract}

Keywords: hydrogels, intergel systems, reciprocal activation, sorption, extraction rate, polymethacrylic acid, poly-4-vinylpyridine, uranyl ion.

\section{Introduction}

Rare-earth element containing ores extraction is often complicated in terms of their radioactivity, which is caused by containing uranium, thorium, and their half-life products in their composition. Due to this fact, the issue of rare-earth elements separation from radioactive elements, particularly uranium, is of high importance nowadays [1-3]. Uranium can be removed from solutions by sorption, extraction, and other methods. At present, sorption methods are more preferred than extraction ones. Sorption methods are more ecofriendly and have fewer technological cycles than extraction technologies $[4,5]$. Ion-exchange uranium extraction process is based on ion-exchange resins ability to absorb uranium selectively and quantitively from solutions and pulps after lixiviation. In sulfurous solutions, hexavalent uranium can be present as uranyl cation $\left(\mathrm{UO}_{2}{ }^{2+}\right)$ and as anion sulphatic complexes $\left(\left[\mathrm{UO}_{2}\left(\mathrm{SO}_{4}\right)_{2}\right]^{2},\left[\mathrm{UO}_{2}\left(\mathrm{SO}_{4}\right)_{3}\right]^{4-}\right)[6]$.

The objective of our research is to study functional hydrogels initial state and remote interaction (activation) time influence on polymers ratio in intergel systems, depth of uranyl ions sorption during their interaction with intergel systems and prospects of using these intergel systems for uranium extraction from product solutions.

\section{Experimental}

Equipment. A MARK 603 conductometer (Russia) and Metrohm 827 pH-Lab pH-meter (Switzerland) were used for measuring specific electrical conductivity and solutions $\mathrm{pH}$. Sorbent mass was determined by weighing at electronic analytical scales MSE125P-100-DU Sartorius Cubis (Germany).

Materials. The research was performed in water environment and in solution of hexaqua uranyl nitrate $\left(\mathrm{UO}_{2}{ }^{2+}\right.$ concentration $\left.=100 \mathrm{mg} / \mathrm{l}\right)$. Cross-linked by divinylbenzene hydrogel poly-4-vinylpyridine (hP4VP) of Sigma-Aldrich was used. Polymethacrylic acid hydrogels were synthesized applying cross-linking agent $\mathrm{N}$,N-methylene-bis-acrylamide and red-ox system $\mathrm{K}_{2} \mathrm{~S}_{2} \mathrm{O}_{8}-\mathrm{Na}_{2} \mathrm{~S}_{2} \mathrm{O}_{3}$ in water environment. Synthesized 
PMAA hydrogel was reduced to smaller dispersions and separated by size. Fractions of $250<\mathrm{d}<425 \mu \mathrm{m}$ were used in the process. Hydrogel swelling ratios were $\alpha_{(\mathrm{hPMAA})}=21.00 \mathrm{~g} / \mathrm{g}, \alpha_{(\mathrm{hP} 4 \mathrm{VP})}=3.20 \mathrm{~g} / \mathrm{g}$.

For the research objective, synthesized hPMAA and hP4VP hydrogels were combined into polymethacrylic acid gel - poly-4-vinylpyridine gel (hPMAA-hP4VP) intergel couple.

Experiment. Experiments were carried out at room temperature. hPMAA and hP4VP hydrogels were taken in swollen state. Study of the intergel systems was done as follows: each hydrogel in dry state was placed in separate polypropylene cages. hPMAA and hP4VP hydrogels were previously left in distilled water for 24 hours for swelling. Then polypropylene cages with swollen hydrogels were placed in glasses with water and hexaqua uranyl nitrate solutions. Electroconductivity and overgel liquid $\mathrm{pH}$ were determined with hydrogels present in the solution.

Research of individual polymeric hydrogels sorption properties was done as follows:

1) Estimated amount of each hydrogel (polymethylacrylic acid, poly-4-vinylpyridine) in dry state was placed into polypropylene cages.

2) Uranyl ions sorption by individual hydrogels of PMAA and P4VP was done for 56 hours. During this period aliquots were taken for further determination of uranyl ions concentration.

Research of intergel systems sorption properties was done as follows:

1) Intergel system hPMAA-hP4VP was combined from synthesized PMAA and P4VP hydrogels;

2) Estimated amount of each hydrogel in dry state was placed into polypropylene cages;

3) Uranyl ions sorption by these intergel systems was done for 56 hours. During this period aliquots were taken for further determination of uranyl ions concentration.

Uranyl ions determination procedure. Measurement of uranium mass concentration was carried out by volumetric titanium-phosphate-vanadate method based on red-ox properties of uranium (IV) and uranium (VI) and its reduction and oxidation reactions.

Uranyl ions extraction (sorption) rate was calculated according to the formula:

$$
\eta=\frac{C_{i n}-C_{r e s}}{C_{\text {in }}} * 100 \%,
$$

where $C_{\text {in }}$ is uranyl ions initial concentration in solution, $\mathrm{mg} / \mathrm{l} ; C_{\text {res }}$ is uranyl ions residual concentration in solution, $\mathrm{mg} / \mathrm{l}$.

Total polymer chain binding rate was calculated according to the formula:

$$
\theta=\frac{v_{\text {sor }}}{v} * 100 \%
$$

where $v_{\text {sor }}$ is an amount of sorbed uranyl ions, mole; $v$ is hydrogel weighed portion (if two hydrogels are present in the solution, this is calculated as summed amount of each of them), mole.

Effective dynamic exchange capacity of individual hydrogels and intergel system was calculated according to the formula:

$$
Q=\frac{v_{\text {sor }}}{m_{\text {sorbent }}}
$$

where $v_{\text {sor }}$ is an amount of sorbed uranyl ions, mole; $m$ is polymer weighed portion (if two hydrogels are present in the solution, this is calculated as summed weight of each of them), $g$.

Calculation of total inactivated hydrogels PMAA and P4VP sorption rate was done according to the formula:

$$
\sum \eta=\left(\frac{\eta_{1} * 83 \%}{100 \%}+\frac{\eta_{2} * 17 \%}{100 \%}\right)
$$

where $\eta_{1}$ is $83 \%$ hPMAA uranyl ions extraction rate, $\% ; \eta_{2}$ is $17 \%$ hP4VP uranyl ions extraction rate, $\%$.

\section{Results and Discussion}

Previously performed studies [7, 8] have shown that almost all intergel systems based on acidic (polyacrylic and polymethacrylic acids) and basic (poly-4-vinylpyridine and poly-2-methyl-5-pyridine) lightly cross-linked polymeric hydrogels display higher activity than their initial components. It has also been found that polymer ratios, which provide higher ions sorption, differ significantly depending on nature of acidic and basic hydrogels and nature of rare-earth metals.

These results were obtained after studying sorption of lanthanum, cerium, dysprosium, neodymium, samarium, and erbium by intergel systems. Influence of initial hydrogel state on sorption process was also 
identified. Depending on what gel is used for intergel couple formation (dry, swollen or partially swollen) there can be different hydrogel ratios in intergel systems with high sorption capacity and rare-earth metal ions sorption rate. However, no work was done to determine optimal conditions for maximum sorption and ions selectivity in case of using intergel systems for uranyl ions extraction.

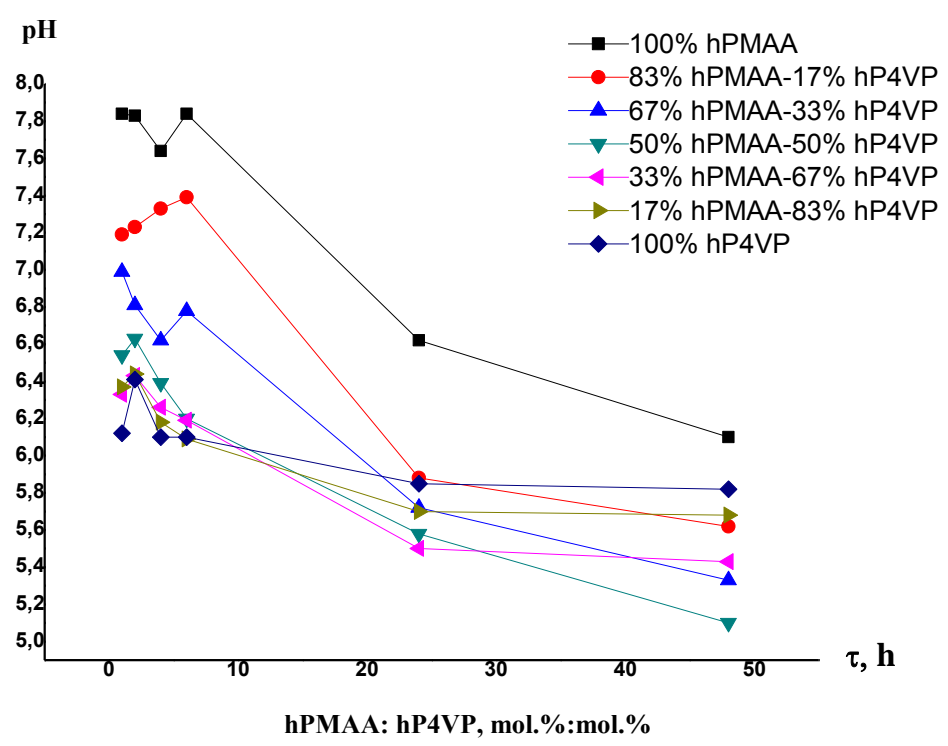

Figure 1. Water solutions pH dependency on time in the presence of hPMAA-hP4VP intergel system

Figure 1 illustrates water solutions $\mathrm{pH}$ dependency on time in the presence of hPMAA-hP4VP intergel system. It can be seen that initial PMAA hydrogel and intergel systems within ratios of $83 \%$ hPMAA:17\% hP4VP and 50\% hPMAA:50 \% hP4VP have significantly lower $\mathrm{pH}$, which is caused by $\mathrm{H}^{+}$ions emission into solution as a result of functional carboxylic groups dissociation process. Twenty four hours later dissociation continues less intensive, which indicates approaching electrochemical equilibrium in the solution. Initial P4VP hydrogel and intergel systems within ratios of $33 \%$ hPMAA:67\% hP4VP and $17 \%$ hPMAA: $83 \%$ hP4VP have minor $\mathrm{pH}$ decrease in initial area, which is most likely caused by solution protons binding by nitrogen atom in vinylpyridine. Forty eight hours later the systems did not show $\mathrm{pH}$ changes.

As a result of remote interaction, hydrogels form functional groups without counter-ions, which leads to significant increase of intergel system sorption capacity.

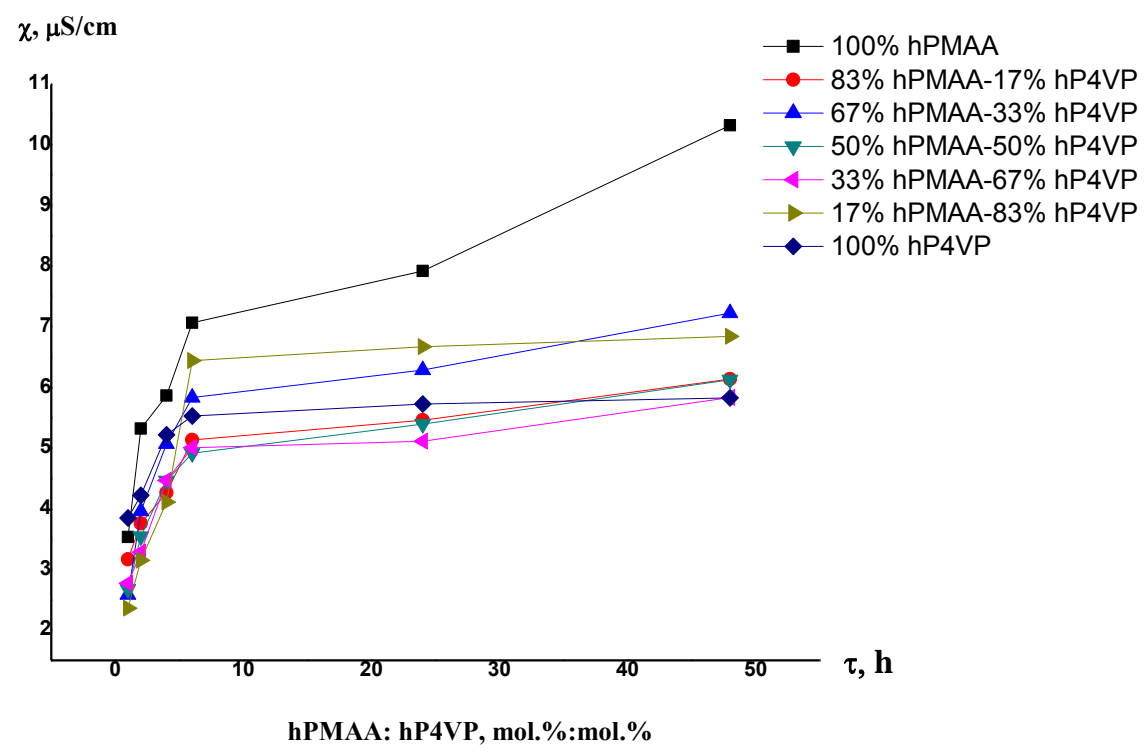

Figure 2. Water solutions' specific electrical conductivity time dependence in the presence of hPMAA-hP4VP intergel system 
Figure 2 shows hPMAA-hP4VP water solutions' specific electrical conductivity time dependence. When environment $\mathrm{pH}$ decreases, concentration of $\mathrm{H}^{+}$ions or $\mathrm{H}_{3} \mathrm{O}^{+}$hydroxonium increases, which leads to specific electrical conductivity rise. It can be noticed from Figure 2 that, water electrical conductivity increases over time in the presence of initial PMAA hydrogel. This is facilitated by functional group dissociation at macromolecule interstitial units. As a result, hydrogen ions are emitted into the solution and carboxylate anions are formed. Initial P4VP hydrogel and intergel systems display specific electrical conductivity increase only at an early stage. Further rise during 24-hour period is not intense. Then during 48-hour period specific electrical conductivity increase is almost not seen, which suggests that electrochemical equilibrium is reached.

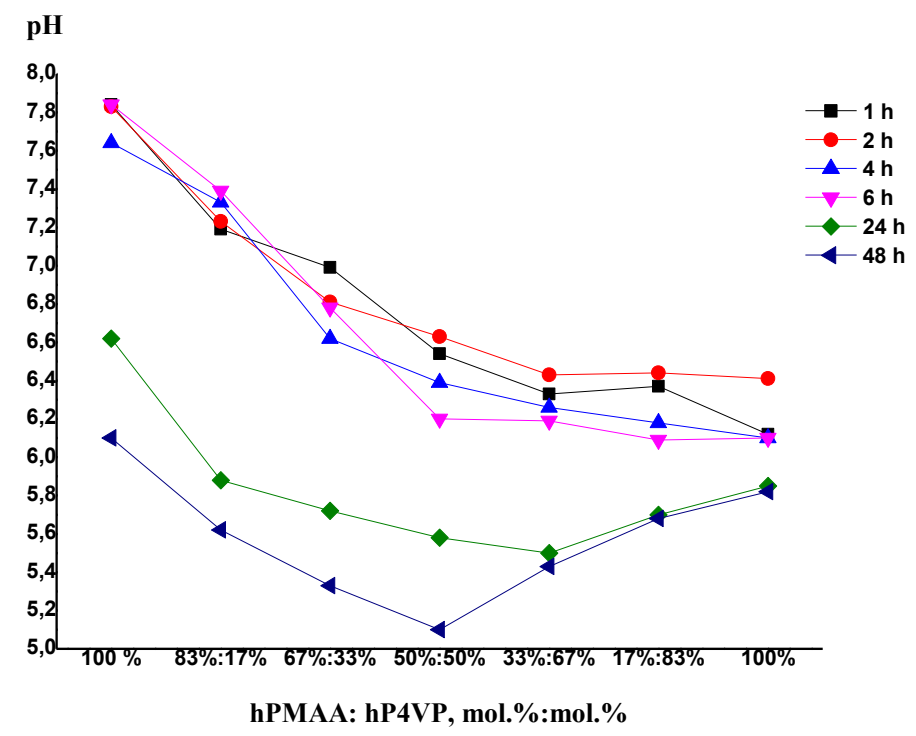

Figure 3 (a). Water solutions $\mathrm{pH}$ dependence on hPMAA-hP4VP mole ratio over time

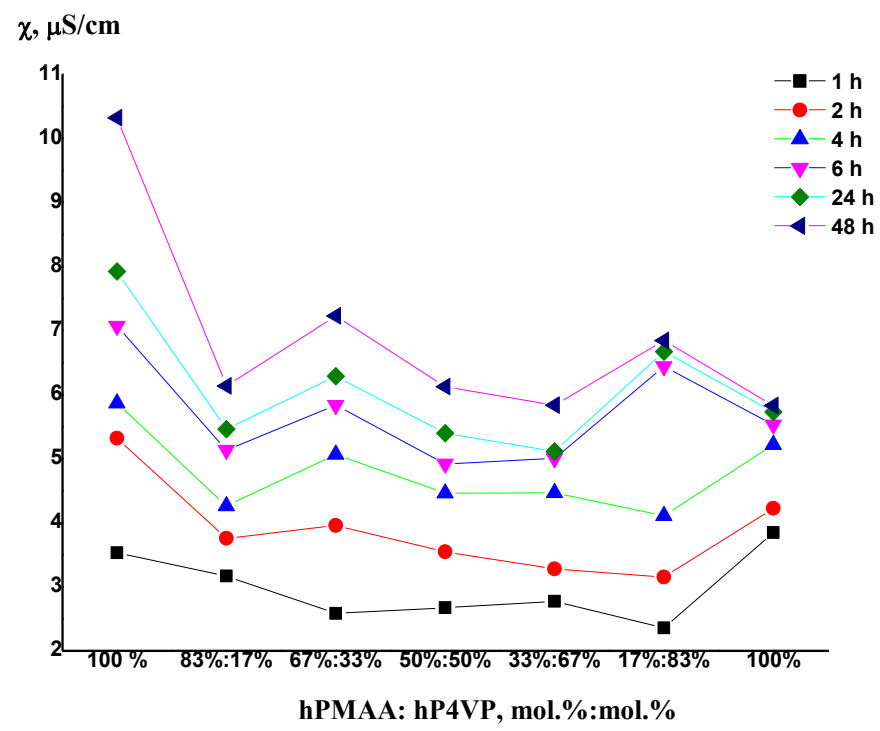

Figure 3 (b). Water solutions specific electrical conductivity dependence on hPMAA-hP4VP mole ratio over time

Figure $3 a, b$ represents hydrogen ions concentration and solutions' specific electrical conductivity change dependence on hydrogels mole ratio over time. Initial PMAA hydrogel and intergel systems within ratios of $83 \%$ hPMAA: $17 \% \mathrm{hP} 4 \mathrm{VP}$ and $50 \% \mathrm{hPMAA}: 50 \% \mathrm{hP} 4 \mathrm{VP}$ display reduction of solutions $\mathrm{pH}$. When environment $\mathrm{pH}$ decreases, concentration of $\mathrm{H}^{+}$ions, $\mathrm{H}_{3} \mathrm{O}^{+}$hydroxonium or other ions increases, which leads to specific electrical conductivity rise. Besides, new negatively charged ions may appear in the system. Increase of $\mathrm{H}^{+}$ions concentration happens due to PMAA hydrogel functional carboxylic groups' 
dissociation. Initial PMAA hydrogel and intergel systems within ratios of $33 \%$ hPMAA:67 \% hP4VP and $17 \%$ hPMAA:81 \% hP4VP display no significant changes in $\mathrm{H}^{+}$ions content. Water solution's specific electrical conductivity rise during hydrogels remote interaction when $\mathrm{H}^{+}$ions concentration does not change may be caused by $\mathrm{OH}^{-}$ions presence in the solution as a result of interaction between P4VP hydrogel polybase and water molecules.

By virtue of the processes mentioned above, hydrogels mutual activation happens. This implies hydrogels switching to highly ionized state, which leads to significant increase of intergel system sorption capacity.

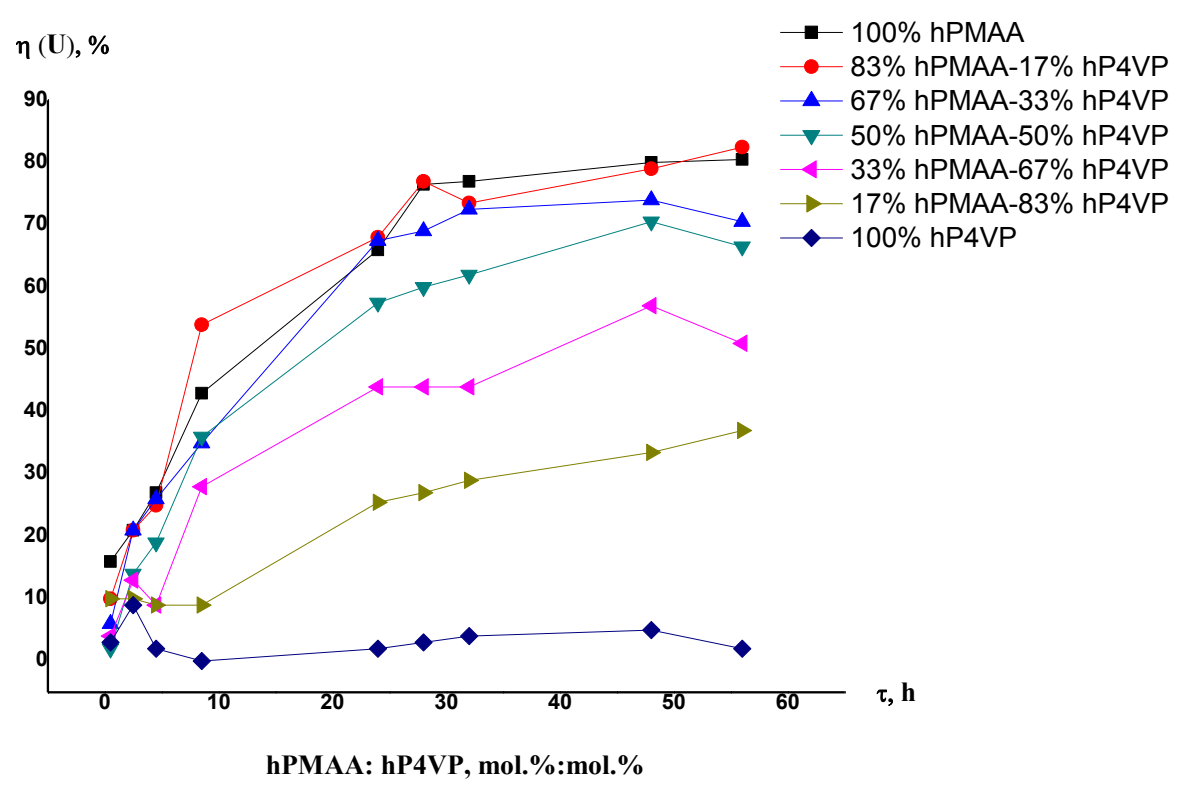

Figure 4. Dependence of uranyl ions extraction rate by hPMAA-hP4VP intergel systems over time

Figure 4 demonstrates dependence of uranyl ions extraction rate by initial hydrogels and hPMAAhP4VP intergel systems over time. It should be noted that polymeric macromolecules switching to highly ionized state due to hydrogels mutual activation during their remote interaction leads to significantly increased uranyl ions extraction rate with polymeric hydrogels in intergel couples in comparison with initial hydrogels.

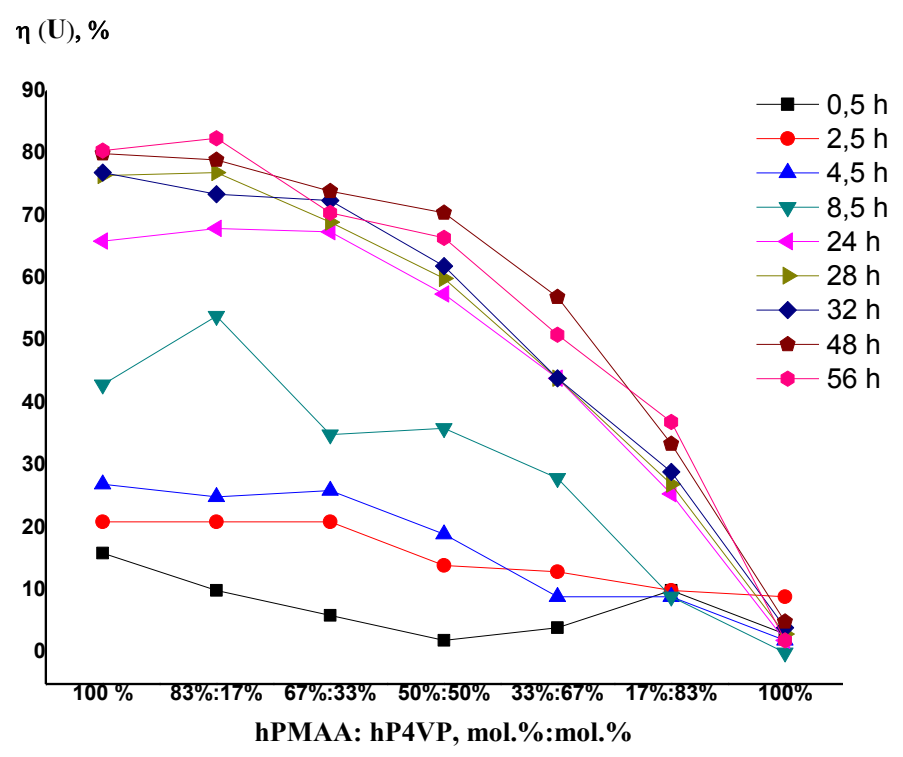

Figure 5. Dependence of uranyl ions extraction rate by hPMAA-hP4VP intergel systems on hydrogels mole ratio over time 
Major amount of uranyl ions is sorbed by initial PMAA hydrogel and intergel systems over 56 hours of their interaction with salt solutions. Maximum uranyl ions extraction rate, namely $82.5 \%$ is observed in intergel system within the ratios of $100 \% \mathrm{hPMAA}$ and $67 \%$ hPMAA:33 \% hP4VP 56 hours later. Uranyl ions extraction rate by initial polymeric hydrogels $100 \%$ hPMAA and $100 \% \mathrm{hP} 4 \mathrm{VP}$ is $80.5 \%$ and $2.0 \%$, respectively. Initial P4VP hydrogel shows minor sorption rate only at an early stage, it remains unchanged over time. However, P4VP hydrogel, not having significant uranyl ions sorption rate, participates in initial PMAA hydrogel activation, which can be seen prominently within the ratios of $100 \%$ hPMAA and $67 \%$ hPMAA:33\% hP4VP.

Figure 5 indicates dependence of uranyl ions extraction rate by hPMAA-hP4VP intergel systems on hydrogels mole ratio over time. It can be seen from the graph that the highest uranyl ions sorption happens within ratio of $83 \%$ hPMAA: $17 \% \mathrm{hP} 4 \mathrm{VP}$. Especially high-sorption rate increase is observed after 8.5 hours; uranyl ions extraction rate at this point is $54.0 \%$. Uranyl ions extraction rate by individual polymeric hydrogels $100 \% \mathrm{hPMAA}$ and $100 \% \mathrm{hP} 4 \mathrm{VP}$ is $43.0 \%$ and $0.0 \%$, respectively. The main reason for such a high extraction rate is high ionization of polymeric structures as a result of their mutual activation.

For the purpose of estimating intergel systems' sorption activity within the ratios of $100 \%$ hPMAA and $67 \%$ hPMAA:33\% hP4VP in comparison with initial PMAA and P4VP hydrogels, $83 \%$ hPMAA:17 \% hP4VP intergel systems were selected and summary calculations of extraction rates were done individually for inactivated $83 \% \mathrm{hPMAA}$ and $17 \% \mathrm{hP} 4 \mathrm{VP}$ hydrogels. Based on the results, difference of total extraction rates between initial hydrogels and intergel systems was calculated. The outcomes show that intergel system due to mutual activation has a higher uranyl ions sorption capacity than initial hydrogels. For calculation of hydrogels activity through initial inactivated $100 \%$ hPMAA and $100 \% \mathrm{hP} 4 \mathrm{VP}$ hydrogels, an assumption was made of initial hydrogels sorption capacity persistency in case of their concentration decrease in water environment. The obtained data are shown in Table 1 and it is seen that intergel system sorption capacity increase in relation to initial inactivated hydrogels over time occurs differently. 0.5 hour later, there is no sorption rate increase; 2.5 hours later sorption rate increase is $10.53 \%$. Then 4.5 hours later, there is minor decrease of sorption rate; the rate at this moment is $9.65 \% .8 .5$ hours later, there is a rapid increase of intergel system's sorption capacity, namely $50.84 \%$. Then, during 32-hour period, there is another decrease of sorption activity; subsequently, after reaching 48-hour time, there is an increase. Intergel system's sorption rate increase in relation to initial inactivated hydrogels according to calculation data was $19.39 \%$. This dynamics of intergel system's sorption activity change in relation to initial inactivated hydrogels that is most likely related to a group of factors, one of which is conformational transformations significantly influencing reaction mechanism. This way, intergel system's sorption capacity increase calculations point out a significant increase of intergel system's sorption capacity in relation to initial inactivated hydrogels.

Table 1

Experimental results with 83 \%hPMAA:17 \%hP4VP ratio of intergel system extraction rates and total calculation data of inactivated hydrogels

\begin{tabular}{|l|c|c|c|c|c|c|c|c|c|}
\hline \multicolumn{1}{|c|}{ Sorption parameters } & \multicolumn{7}{|c|}{ Sampling period, hours } \\
\cline { 2 - 10 } & 0.5 & 2.5 & 4.5 & 8.5 & 24 & 28 & 32 & 48 & 56 \\
\hline $\begin{array}{l}100 \% \text { hPMAA initial hydrogel ex- } \\
\text { traction rate }\end{array}$ & 16.0 & 21.0 & 27.0 & 43.0 & 66.0 & 76.5 & 77.0 & 80.0 & 80.5 \\
\hline $\begin{array}{l}100 \% \text { hP4VP initial hydrogel extrac- } \\
\text { tion rate }\end{array}$ & 3.0 & 9.0 & 2.0 & 0.0 & 2.0 & 3.0 & 4.0 & 5.0 & 2.0 \\
\hline $\begin{array}{l}83 \% \text { hPMAA inactivated hydrogel } \\
\text { extraction rate calculation data }\end{array}$ & 13.3 & 17.5 & 22.5 & 35.8 & 55.0 & 63.8 & 64.2 & 66.7 & 68.8 \\
\hline $\begin{array}{l}17 \% \text { hP4VP inactivated hydrogel } \\
\text { extraction rate calculation data }\end{array}$ & 0.5 & 1.5 & 0.3 & 0.0 & 0.3 & 0.5 & 0.7 & 0.8 & 0.3 \\
\hline $\begin{array}{l}83 \% \text { hPMAA and 17 \% hP4VP inac- } \\
\text { tivated hydrogels extraction rate } \\
\text { summary calculation data }\end{array}$ & 13.8 & 19.0 & 22.8 & 35.8 & 55.3 & 64.3 & 64.9 & 67.5 & 69.1 \\
\hline $\begin{array}{l}\text { 83 \% hPMAA:17 \% hP4VP intergel } \\
\text { system extraction rate }\end{array}$ & 10.0 & 21.0 & 25.0 & 54.0 & 68.0 & 77.0 & 73.5 & 79.0 & 82.5 \\
\hline $\begin{array}{l}\text { intergel system sorption capacity in } \\
\text { relation to initial inactivated } \\
\text { hydrogels, \% }\end{array}$ & 0.00 & 10.53 & 9.65 & 50.84 & 22.97 & 19.75 & 13.25 & 17.04 & 19.39 \\
\hline
\end{tabular}


Table 2 shows polymeric chain binding rates (in relation to uranyl ions) by initial polymers and hPMAA-hP4VP intergel systems over time. The most intense uranyl ions' binding by initial polymers and intergel systems occurs during the period of 48-56 hours. High values of polymeric chain binding rates in relation to uranyl ions are observed within the ratios of $100 \%$ hPMAA and $67 \%$ hPMAA:33 \% hP4VP and equal to $9.94 \%$. This suggests a high rate of molecules ionization as a result of hPMAA and hP4VP polymers mutual activation. hPMAA and hP4VP individual polymers chain binding rates in relation to uranyl ions after 56 hours are $9.70 \%$ and $0.24 \%$, respectively.

Table 2

Polymeric chain binding rates (in relation to uranyl ions)

by initial hydrogels and hPMAA-hP4VP intergel systems over time, \%

\begin{tabular}{|l|c|c|c|c|c|c|c|c|c|}
\hline \multicolumn{10}{|c|}{ Polymer chain binding rate (in relation to uranyl ions), \% } \\
\hline$\tau, \mathrm{h}$ & 0.5 & 2.5 & 4.5 & 8.5 & 24 & 28 & 32 & 48 & 56 \\
\hline $100 \%$ hPMAA & 1.93 & 2.53 & 3.25 & 5.18 & 7.95 & 9.21 & 9.27 & 9.64 & 9.70 \\
\hline $83 \%$ hPMAA:17 \%hP4VP & 1.20 & 2.53 & 3.01 & 6.50 & 8.19 & 9.27 & 8.85 & 9.52 & 9.94 \\
\hline $67 \%$ hPMAA:33 \%hP4VP & 0.72 & 2.53 & 3.13 & 4.22 & 8.13 & 8.31 & 8.73 & 8.91 & 8.49 \\
\hline $50 \%$ hPMAA:50 \%hP4VP & 0.24 & 1.69 & 2.29 & 4.34 & 6.93 & 7.23 & 7.47 & 8.49 & 8.01 \\
\hline $33 \%$ hPMAA:67 \%hP4VP & 0.48 & 1.57 & 1.08 & 3.37 & 5.30 & 5.30 & 5.30 & 6.87 & 6.14 \\
\hline $17 \%$ hPMAA:83 \%hP4VP & 1.20 & 1.20 & 1.08 & 1.08 & 3.07 & 3.25 & 3.49 & 4.04 & 4.46 \\
\hline $100 \%$ hP4VP & 0.07 & 1.08 & 0.24 & 0.00 & 0.24 & 0.36 & 0.48 & 0.60 & 0.24 \\
\hline
\end{tabular}

Table 3 illustrates effective dynamic exchange capacity (in relation to uranyl ions) by initial hydrogels and hPMAA-hP4VP intergel systems over time. The obtained data suggests that polymeric hydrogels' mutual activation in intergel couples leads to significant increase of exchange capacity values in comparison with initial P4VP hydrogel. This is the most distinctive value after 56 hours of remote interaction. Intergel system reaches maximum values of effective dynamic exchange capacity within the ratios of $100 \%$ hPMAA and $67 \%$ hPMAA: $33 \% \mathrm{hP} 4 \mathrm{VP}$ after 56 hours of remote interaction and is $1.12 \mathrm{mmol} / \mathrm{g}$.

Table 3

Effective dynamic exchange capacity (in relation to uranyl ions)

by initial hydrogels and hPMAA-hP4VP intergel systems over time, \%

\begin{tabular}{|l|c|c|c|c|c|c|c|c|c|}
\hline \multicolumn{7}{|c|}{ Effective dynamic exchange capacity (in relation to uranyl ion), mmol/g } \\
\hline$\tau, \mathrm{h}$ & 0.5 & 2.5 & 4.5 & 8.5 & 24 & 28 & 32 & 48 & 56 \\
\hline $100 \%$ hPMAA & 0.22 & 0.29 & 0.38 & 0.60 & 0.92 & 1.07 & 1.08 & 1.12 & 1.11 \\
\hline $83 \%$ hPMAA:17 \%hP4VP & 0.14 & 0.28 & 0.34 & 0.73 & 0.92 & 1.04 & 0.99 & 1.07 & 1.12 \\
\hline $67 \%$ hPMAA:33 \%hP4VP & 0.08 & 0.27 & 0.34 & 0.46 & 0.88 & 0.90 & 0.95 & 0.97 & 0.92 \\
\hline $50 \%$ hPMAA:50 \%hP4VP & 0.03 & 0.18 & 0.24 & 0.45 & 0.73 & 0.76 & 0.78 & 0.89 & 0.84 \\
\hline $33 \%$ hPMAA:67 \%hP4VP & 0.05 & 0.16 & 0.11 & 0.34 & 0.54 & 0.54 & 0.54 & 0.70 & 0.62 \\
\hline $17 \%$ hPMAA:83 \%hP4VP & 0.12 & 0.12 & 0.11 & 0.11 & 0.30 & 0.32 & 0.34 & 0.40 & 0.44 \\
\hline $100 \%$ hP4VP & 0.03 & 0.10 & 0.02 & 0.00 & 0.02 & 0.03 & 0.05 & 0.06 & 0.02 \\
\hline
\end{tabular}

\section{Conclusions}

During the research, it was identified that hydrogels maximum activity was within the ratios of $100 \%$ hPMAA and $67 \%$ hPMAA:33 \% hP4VP. Due to hydrogels mutual activation during their remote interaction, polymeric macromolecules switch to a highly ionized state, which leads to a significant increase of polymeric hydrogels uranyl ions extraction rate in intergel couples in comparison with initial polymers. The highest uranyl ions sorption by intergel system occurs at $83 \%$ hPMAA:17\% hP4VP ratio. Maximum uranyl ions extraction rate after 56 hours of hydrogels remote interaction was $82.5 \%$, when polymeric chain binding rate was $9.94 \%$, and effective dynamic exchange capacity was $1.12 \mathrm{mmol} / \mathrm{g}$. Significant increase of uranyl ions sorption rate by intergel system in comparison with initial hydrogels is related to high rate of hydrogels ionization in intergel couple. Considerable increase of intergel system sorption activity within the ratios of $100 \% \mathrm{hPMAA}$ and $67 \% \mathrm{hPMAA}: 33 \% \mathrm{hP} 4 \mathrm{VP}$ in comparison with initial inactivated $100 \%$ hPMAA and $100 \%$ hP4VP hydrogels was confirmed by combined calculation data of extraction rates of 
inactivated PMAA and P4VP polymeric hydrogels. Intergel system's sorption activity in comparison with initial inactivated hydrogels grows differently over time. Especially high increase of intergel system's sorption activity, namely $50.84 \%$ can be seen after 8.5 hours. Intergel system's sorption rate in comparison with initial inactivated hydrogels after 56 hours was $19.39 \%$, according to calculation data. The obtained results suggest that intergel systems can be used for highly efficient sorption technology of extracting uranyl ions and other elements from commercial solutions as well as for concentration, separation of different ions from water solutions for performing technological, environmental, and other objectives.

\title{
References
}

1 Lapidus G.T. Selective thorium and uranium extraction from monazite: II. Approaches to enhance the removal of radioactive contaminants/ G.T. Lapidus, F.M. Doyle // Hydrometallurgy. — 2015. — Vol. 155. — P. 161-167. https://doi.org/10.1016/ j.hydromet.2015.03.015

2 Garcia A.C. Separation of Radioactive Elements from Rare Earth Element-Bearing Minerals/ A.C. Garcia, M. Latifi, A. Amini, J. Chaouki // Metals. — 2020. — Vol. 10, No. 11. — P. 1524. https://doi.org/10.3390/met10111524

3 Yanliang Wang. Process for the separation of thorium and rare earth elements from radioactive waste residues using Cyanex ${ }^{\circledR} 572$ as a new extractant / Yanliang Wang, Chao Huang, Fujian Li, Yamin Dong, Xiaoqi Sun // Hydrometallurgy. — 2017. — Vol. 169. — P. 158-164. https://doi.org/10.1016/j.hydromet.2017.01.005

4 Самойлов В.И. Анализ состояния технологии сорбционного извлечения урана в гидрометаллургических урановых производствах / В.И. Самойлов, А.Т. Садуакасова, Н.А. Куленова // Международный журнал экспериментального образования. - 2015. — № 5-1. — С. 80-87.

5 Abdikerim B.E. Uranium extraction with modified sorbents/ B.E. Abdikerim, B.K. Kenzhaliyev, T.Yu. Surkova, N. Didik, A.N. Berkinbayeva, Z.D. Dosymbayeva, N.S. Umirbekova // Kompleksnoe ispolzovanie mineralnogo syria = Complex Use of Mineral Resources = Mineraldik Shikisattardy Keshendi Paidalanu. — 2020. — № 3 (314). — P. 84-90. https://doi.org/10.31643/ 2020/6445.30

6 Тураев Н.С. Химия и технология урана: учеб. пос. для вузов / Н.С. Тураев, И.И. Жерин. — М.: ЦНИИАТОМИНФОРМ, 2005. - $407 \mathrm{c}$.

7 Alimbekova B.T. Features of polymethacrylic acid and poly-2-methyl-5-vinylpyridine hydrogels remote interaction in an aqueous medium / B.T. Alimbekova, Zh.K. Korganbayeva, H. Himersen, R.G. Kondaurov, T.K. Jumadilov // Journal of chemistry and chemical engineering. — 2014. - Vol. 3, № 8. - P. 265-269. https://doi.org/10.17265/1934-7375/2014.03.008

8 Jumadilov T.K. Influence of polyacrylic acid and poly-4-vinylpyridine hydrogels mutual activation in intergel system on their sorption properties in relation to lanthanum (III) ions / T.K. Jumadilov, R.G. Kondaurov, Zh.A. Abilov, J.V. Grazulevicius, A.A. Akimov // Polymer Bulletin. — 2017. — Vol. 74. — P. 4701-4713. https://doi.org/10.1007/s00289-017-1985-3

\author{
Т.Қ. Жұмаділов, А.А. Утешева, Х. Химэрсэн, \\ Р.Г. Кондауров, Ю.В. Гражулявичюс
}

\section{Полиметакрил қышқылы-поли-4-винилпиридин интергелді жүйелерімен уранил иондарын сорбциялау барысындағы функционалды топтардың аномальды активтілігі}

\begin{abstract}
Полиметакрил қышқылы (ПМАҚг) және поли-4-винилпиридин (П4ВПг) гидрогелдерінен тұратын интергелді жүйелердің уранил иондарына сорбциясы қарастырылған. Интергелді жүйелердің сорбциясын болжау үшін алдымен полимерлік гидрогелдердің (ПМАҚг, П4ВПг) су ортасындағы өзара активтену процесі зерттелді. Алынған нәтижелер негізінде гидрогелдердің максималды активтенуі 100 \% ПМАҚг, 67 \% ПМАҚг : 33 \% П4ВПг қатынастарында болатыны анықталды. Уранил иондарын максималды шығару дәрежесі осы қатынастарда байқалады. Интергелді жүйелердің уранил иондарына максималды сорбциясы 83 \% ПМАҚг : 17 \% П4ВПг қатынастарында болатыны табылды. Гидрогелдердің қашықтан өзара әрекеттесуінің 56 сағатынан кейін уранил иондарын максималды шығару дәрежесі 82,5 \%, полимерлік тізбектің байланысу дәрежесі 9,94 \% және тиімді динамикалық алмасу сиымдылығы - 1,12 ммоль/г болды. Бастапқы активтенбеген $100 \%$ ПМАҚг және $100 \%$ П4ВПг гидрогелдерімен салыстырғанда интергелді жүйелердің сорбциялық белсенділігінің $100 \%$ ПМАҚг, 67 \% ПМАҚг:33 \% П4ВПг қатынастарында анағұрлым жоғары болатынын активтенбеген гидрогелдердің жалпы есептік мәндері дәлелдеді. Алынған нәтижелер интергелді жүйелерде бастапқы полимерлік гидрогелдердің электрохимиялық және сорбциялық қасиеттерінің өзгеретінін, яғни функционалды топтардың реакцияға түсу қабілеті артатынын көрсетті. Бұл оларды уранил иондарын шығарудың жоғары тиімді сорбциялық технологиясын жасау үшін қолдануға мүмкіндік береді.
\end{abstract}


Кілm сөздер: гидрогелдер, интергелді жүйелер, өзара активтену, сорбция, шығару дәрежесі, полиметакрил қышқылы, поли-4-винилпиридин, уранил ионы.

\author{
Т.К. Джумадилов, А.А. Утешева, Х. Химэрсэн, \\ Р.Г. Кондауров, Ю.В. Гражулявичюс
}

\title{
Аномальная активность функциональных групп при сорбции ионов уранила интергелевой системой «полиметакриловая кислота - поли-4-винилпиридин»
}

\begin{abstract}
Изучена сорбция ионов уранила интергелевой системой, состоящей из гидрогеля полиметакриловой кислоты (гПМАК) и гидрогеля поли-4-винилпиридина (гП4ВП). Для прогнозирования сорбционной активности интергелевой системы первоначально была изучена взаимная активация полимерного гидрогеля ПМАК с П4ВП в водной среде. На основе полученных результатов было установлено, что область максимальной активации гидрогелей находится в пределах соотношений между $100 \%$ гПМАК и $67 \%$ гПМАК : 33 \% гП4ВП. В этой же области наблюдается максимальная степень извлечения ионов уранила. Установлено, что наибольшая сорбция ионов уранила интергелевой системой происходит при соотношении $83 \%$ гПМАК : $17 \%$ гП4ВП. Максимальная степень извлечения ионов уранила по истечении 56 ч дистанционного взаимодействия гидрогелей составила $82,5 \%$, при этом степень связывания полимерной цепи равнялась 9,94\%, а эффективная динамическая обменная емкость - 1,12 ммоль/г. Значительный рост сорбционной активности интергелевых систем в пределах соотношений между $100 \%$ гПМАК и $67 \%$ гПМАК : $33 \%$ гП4ВП, по сравнению с исходными неактивированными гидрогелями $100 \%$ гПМАК и $100 \%$ гП4ВП, подтвердил суммарные расчётные данные степеней извлечения неактивированных гидрогелей ПМАК и П4ВП. Полученные результаты свидетельствуют об изменении электрохимических, сорбционных свойств исходных полимерных гидрогелей в интергелевой системе, приводящем к тому, что функциональные группы приобретают более высокую реакционную способность, и предоставляют возможность их применения в последующей разработке высокоэффективной сорбционной технологии извлечения ионов уранила.
\end{abstract}

Ключевые слова: гидрогели, интергелевые системы, взаимная активация, сорбция, степень извлечения, полиметакриловая кислота, поли-4-винилпиридин, ион уранила.

\section{References}

1 Lapidus, G.T., \& Doyle, F.M. (2015). Selective thorium and uranium extraction from monazite: II. Approaches to enhance the removal of radioactive contaminants. Hydrometallurgy, 155, 161-167. https://doi.org/10.1016/j.hydromet.2015.03.015

2 Garcia, A.C., Latifi, M., Amini, A., \& Chaouki, J. (2020). Separation of Radioactive Elements from Rare Earth ElementBearing Minerals. Metals, 10(11), 1524. https://doi.org/10.3390/met10111524

3 Yanliang, Wang, Chao, Huang, Fujian, Li, Yamin, Dong, \& Xiaoqi, Sun. (2017). Process for the separation of thorium and rare earth elements from radioactive waste residues using Cyanex ${ }^{\circledR} 572$ as a new extractant. Hydrometallurgy, 169, $158-164$. https://doi.org/10.1016/j.hydromet.2017.01.005

4 Samoilov, V.I., Saduakasova, A.T., \& Kulenova, N.A. (2015). Analiz sostoianiia tekhnologii sorbtsionnogo izvlecheniia urana $\mathrm{v}$ gidrometallurgicheskikh uranovykh proizvodstvakh [Analysis of the state of the technology of sorption extraction of uranium in hydrometallurgical uranium production]. Mezhdunarodnyi zhurnal eksperimentalnogo obrazovaniia - International Journal of Experimental Education, 5-1, 80-87 [in Russian].

5 Abdikerim, B.E., Kenzhaliyev, B.K., Surkova, T.Yu., Didik, N., Berkinbayeva, A.N., Dosymbayeva, Z.D., \& Umirbekova, N.S. (2020). Uranium extraction with modified sorbents. Kompleksnoe ispolzovanie mineralnogo syria = Complex Use of Mineral Resources = Mineraldik Shikisattardy Keshendi Paidalanu, 3(314), 84-90. https://doi.org/10.31643/2020/6445.30

6 Turaev, N.S., \& Zherin, I.I. (2005). Khimiia i tekhnologiia urana [Uranium chemistry and technology]. Moscow: TsNIIATOMINFORM [in Russian].

7 Alimbekova, B.T., Korganbayeva, Zh.K., Himersen, H., Kondaurov, R.G., \& Jumadilov, T.K. (2014). Features of polymethacrylic acid and poly-2-methyl-5-vinylpyridine hydrogels remote interaction in an aqueous medium. Journal of chemistry and chemical engineering, 3, 8, 265-269. https://doi.org/10.17265/1934-7375/2014.03.008

8 Jumadilov, T.K., Kondaurov, R.G., Abilov, Zh.A., Grazulevicius, J.V., \& Akimov, A.A. (2017). Influence of polyacrylic acid and poly-4-vinylpyridine hydrogels mutual activation in intergel system on their sorption properties in relation to lanthanum (III) ions. Polymer Bulletin, 74, 4701-4713. https://doi.org/10.1007/s00289-017-1985-3 


\section{Information about authors}

Jumadilov Talkybek Kozhataevich - Doctor of Chemical Sciences, Professor, Chief Researcher at JSC "Institute of Chemical Sciences named after A.B. Bekturov", Academician of the Russian Academy of Natural History, 106 Valikhanov street, 050013, Almaty, Kazakhstan, e-mail: jumadilov@mail.ru, https://orcid.org/0000-0001-9505-3719;

Utesheva Ainamgul Altaevna (corresponding author) — Master of Science, PhD student at JSC "Kazakh-British Technical University", School of Chemical Engineering, 59 Tole bi street, 050000, Almaty, Kazakhstan, e-mail: utesheva_93@bk.ru, https://orcid.org/0000-0002-6243-1610;

Khimersen Khuangul - Master of Science, PhD student at Abai Kazakh National Pedagogical University, 13 Dostyk avenue, 050013, Almaty, Kazakhstan, e-mail: huana88@mail.ru; https://orcid.org/00000002-5138-5997;

Kondaurov Ruslan Gennadievich - $\mathrm{PhD}$, Head of the Laboratory of Synthesis and Physicochemistry of Polymers at JSC "Institute of Chemical Sciences named after A.B. Bekturov", 106 Valikhanov street, 050013, Almaty, Kazakhstan, e-mail: r-kondaurov@ mail.ru, https://orcid.org/0000-00015998-8453;

Juozas Vidas Grazulevicius - Doctor of Chemical Sciences, Professor at Kaunas University of Technology, Department of Polymer Chemistry and Technology, K. Donelaičio St. 73,44249, Kaunas, Lithuania, e-mail: juozas.grazulevicius@ktu.lt, https://orcid.org/0000-0002-4408-9727. 